\title{
PENINGKATAN KUALITAS PEMBELAJARAN MELALUI PENERAPAN MANAJEMEN KELAS BEGINNING OF EFFECTIVE TEACHING MATA KULIAH PENDIDIKAN KEWARGANEGARAAN
}

\author{
Fitria Dwi Prasetyaningtyas $^{\bowtie 1}$, Desi Wulandari ${ }^{2}$, dan Nugraheti Sismulyasih ${ }^{3}$
}

Universitas Negeri Semarang

\begin{abstract}
Info Artikel Abstract
Sejarah Artikel:

Diterima: 19 Jan 2018

Direvisi : 20 Mar 2018

Dipublikasikan: Jun 2018

Keywords:

quality of learning,

classroom management

beginning of effective

teaching, civics

The purpose of this study is to describe (1) the implementation of learning through the Application of Classroom Management Beginning Of Effective Teaching Citizenship Education Course (2) enhancing the understanding of Citizenship Education Course with the application of Classroom Management Beginning Of Effective Teaching.

This research is a mixture of quantitative and quantitative research. Qualitative research was chosen to describe the application of the Beginning Of Effective Teaching Classroom Management approach. Quantitative research in the form of pre-experimental design is one -group pretest-posttest design, to see the conceptual understanding of students before and after the application of the Classroom Management approach Beginning Of Effective Teaching.

The results of his research (1) the implementation of learning with Beginning Of Effective Teaching Management approach implemented by learning steps $(a)$ opening, $b$ ) ice breaking, $(c)$ presentation (teaching material), (d) exercises and correction, (e) students talk time (learner speaking time) (f). explanation conclusions and closing (explanatory and closing conclusions). (2) the application of the Beginning Of Effective Teaching Management approach can improve the understanding for PGSD UNNES students, indicated by the improvement of learning outcomes from pre test (before the learning using Beginning Of Effective Teaching approach) reaches 35,0 average to the learning result from the post test (after learning using the Beginning Of Effective Teaching Management) reaches an average of 74.6.
\end{abstract}

\begin{abstract}
Abstrak
Tujuan penelitian ini yaitu mendeskripsikan (1) pelaksanaan pembelajaran melalui Penerapan Manajemen Kelas Beginning Of Effective Teaching Mata Kuliah Pendidikan Kewarganegaraan (2) peningkatkan pemahaman Mata Kuliah Pendidikan Kewarganegaraan dengan penerapan Manajemen Kelas Beginning Of Effective Teaching.

Penelitian ini merupakan campuran antara penelitian kulaitatif dan kuantitatif. Penelitian kualitatif dipilih untuk mendeskripsikan penerapan pendekatan Manajemen Kelas Beginning Of Effective Teaching. Penelitian kuantitatif yang berupa pre eksperimental design yaitu one -group pretest-postest design, untuk melihat pemahaman konseptual mahasiswa sebelum dan sesudah penerapan pendekatan Manajemen Kelas Beginning Of Effective Teaching

Hasil penelitiannya (1) pelaksanaan pembelajaran dengan pendekatan Manajemen Beginning Of Effective Teaching dilaksanakan dengan langkah-langkah pembelajaran (a) opening (pembuka), (b) ice breaking (menumbuhkan semangat), (c) presentation (mengajarkan materi pelajaran), (d) exercises and correction (latihan dan koreksi), (e) students talk time (waktu berbicara peserta didik) (f). explanation conclusions and closing (kesimpulan penjelasan dan penutupan). (2) penerapan pendekatan Manajemen Beginning of Effective Teaching dapat meningkatkan pemahaman bagi mahasiswa PGSD UNNES, ditunjukkan dengan peningktan hasil belajar dari pre test (sebelum pembelajaran dengan menggunakan pendekatan Manajemen Beginning Of Effective Teaching ) mencapai rata-rata 35,0 menjadi hasil belajar dari post test (sesudah pembelajaran dengan menggunakan Manajemen Beginning Of Effective Teaching) mencapai rata-rata 74,6 .
\end{abstract}

(C) 2018 Universitas Muria Kudus
p-ISSN 2087-9385 e-ISSN 2528-696X

${ }^{\bowtie}$ Alamat korespondensi:

Program Studi Pendidikan Guru Sekolah Dasar

Fakultas Keguruan dan Ilmu Pendidikan Universitas Muria Kudus

Kampus UMK Gondangmanis, Bae Kudus Gd. L. 1t I PO. BOX 53

Kudus

Tlp (0291) 438229 ex.147 Fax. (0291) 437198

E-mail: fitriadwiprasetyaningtyas02@gmail.com 


\section{PENDAHULUAN}

Seiring dengan perkembangan dan perubahan yang terjadi di segala bidang secara global, timbul persaingan kualitas antar manusia. Oleh karena itu pendidikan harus mampu menciptakan manusia-manusia yang berkualitas dan memiliki daya saing, sehingga pendidikan memegang peran yang sangat penting dalam upaya peningkatan sumber daya manusia Indonesia.

Pentingnya pemahaman dan penguasaan materi Pendidikan Kewarganegaraan (PKn) ternyata masih kurang disadari oleh banyak pihak, sehingga dalam proses pembelajarannya terkadang banyak terjadi permasalahan. Adapun permasalahan yang sering muncul diantaranya yakni dalam melaksanakan proses pembelajaran masih berpusat pada pendidik, metode yang digunakan terpusat pada metode ceramah sehingga peserta didik cenderung pasif. Proses ini hanya menekankan pada pencapaian tuntutan kurikulum dan penyampaian tekstual semata daripada mengembangkan kemampuan belajar dan membangun individu.

Kondisi seperti ini tidak akan menumbuhkembangkan aspek kemampuan dan aktivitas peserta didik seperti yang diharapkan. Akibatnya nilai-nilai yang didapat tidak seperti yang diharapkan. Peserta didik merasa bosan dan tidak berminat mengikuti pembelajaran. Hal ini terjadi karena pendidik kurang kreatif dalam menyelenggarakan pembelajaran. Yang paling utama adalah kurangnya pengelolaan kelas yang baik sehingga kegiatan pembelajaran belum dapat dilaksanakan secara maksimal.

Berdasarkan hal tersebut yang paling penting dalam proses pembelajaran adalah bagaimana seorang guru/dosen mengelola kelas terutama bagaimana kemampuan seseorang dalam kegiatan pembukaan di kelas. Kegiatan pembukaan ini sangat penting bagi pembelajaran selanjutya. Jika dalam kegiatan pembukaan dapat menaik dan membuat peserta didik fokus pada pembelajaran maka pembelajaran selanjutnya dapat bejalan dengan baik dan sebaliknya.

Berdasarkan analisis masalah, peneliti menetapkan alternatif tindakan yang tepat untuk meningkatkan kualitas pengelolaan atau manajemen kelas yang baik. Alternatif tindakan yang dipilih yakni dengan melakukan penelitian dengan judul "Peningkatan Kualitas Pembelajaran Melalui Penerapan Manajemen Kelas Beginning Of Effective Teaching Mata Kuliah Pendidikan Kewarganegaraan”.
Berdasarkan uraian analisis latar belakang, masalah dalam penelitian ini yakni 1) bagaimanakah pelaksanaan pembelajaran melalui penerapan Manajemen Kelas Beginning Of Effective Teaching Mata Kuliah Pendidikan Kewarganegaraan?; dan 2) Apakah melalui Manajemen Kelas Beginning Of Effective Teaching mampu meningkatkan kualitas pembelajaran Mata Kuliah Pendidikan Kewarganegaraan?

\section{METODE PENELITIAN}

Jenis penelitian yang digunakan yakni penelitian campuran antara penelitian kualitatif dan kuantitatif. Penelitian deskriptif kualitatif dipilih untuk meneliti pelaksanaan pendekatan manajemen beginning of effective teaching dalam pembelajaran konsep dasar pendidikan kewarganegaraan.

Penelitian kuantitatif yang berupa pre eksperimental design yaitu one-group pretestpost test design, untuk melihat peningkatan hasil belajar kognitif mahasiswa sebelum dan sesudah pendekatan pendekatan manajemen beginning of effective teaching digunakan.

Design one-group pre test-post test dapat dilihat sebagai berikut :

$$
\mathrm{O} 1 \mathrm{X} \mathrm{O} 2
$$

Keterangan :

$\mathrm{O} 1=$ nilai pre test (sebelum perlakuan)

$\mathrm{O} 2$ = nilai post test (setelah diberi perlakuan)

Sumber utama data adalah hasil pengamatan terhadap aktivitas dosen dan aktivitas mahasiswa serta lembar pekerjaan mahasiswa. Jenis data yang diperoleh adalah data kualitatif dan kuantitatif yang terdiri atas hasil pengamatan dan penilaian

Teknik pengambilan data yang dilakukan adalah

(1) Observasi terhadap aktivitas dosen dan mahasiswa dalam kegiatan pembelajaran melalui pendekatan manajemen beginning of effective teaching.

(2) Test yang dilakukan diawal (pre test) sebelum pendekatan manajemen beginning of effective teachingdan di akhir (post test) setelah pendekatan manajemen beginning of effective teachingdilaksanakan.

Analisis data kualitatif dilakukan dengan mengacu pada langkah-langkah berikut: reduksi data, penyajian data, menarik kesimpulan (verivikasi). Sementara itu, analisis data kuantitatif yang berupa tingkat pemahaman 
konseptual mahasiswa dilaksanakan dengan langkah sebagai berikut

1) Menguji normalitas data

2) Menguji peningkatan pemahaman konseptual sebelum dan sesudah penerapan pendekatan manajemen beginning of effective teaching digunakan $t$-test sampel related.

$$
\begin{gathered}
t=\frac{\bar{X}_{1}-\bar{X}_{2}}{s_{X_{1} X_{2}} \cdot \sqrt{\frac{2}{n}}} \\
\text { dimana } \\
s_{X_{1} X_{2}}=\sqrt{\frac{1}{2}\left(s_{X_{1}}^{2}+s_{X_{2}}^{2}\right)}
\end{gathered}
$$

Keterangan

$\bar{X}_{1}=$ Rata - Rata Pretest

$\bar{X}_{2=}$ Rata - Rata Postest

$S 1=$ Simpangan Baku pretest

$S 2=$ Simpangan baku postest

$\mathrm{n} 1$ = banyak data pre test

$\mathrm{n} 2=$ banyak data post test

$\mathrm{r}=$ korelasi pre test dan post test

Data kuantitatif dianalisis menggunakan softare SPSS 16.00, sehingga setelah data pre test dan post test teruji normalitasnya, kemudian dilakukan uji beda dengan paired samples correlation.

\section{HASIL PENELITIAN DAN PEMBAHASAN}

\section{Tahap Persiapan Pelaksanaan} Pembelajaran

Dipersiapkan untuk pelaksanaan perkuliahan dengan materi yang terdiri dari 3 sub materi, yaitu (1) identitas nasional, (2) demokrasi dan (3) konstitusi. Persiapan yang dilakukan oleh dosen adalah menyusun perangkat dan bahan ajar, serta menyiapkan instrument penelitian yang berupa lembar pengamatan pembelajaran dengan penerapan pendekatan manajemen beginning of effective teaching, lembar pengamatan, soal pre test dan post test yang berupa soal uraian sesuai dengan kompetensi dasar dan indikator.

2. Pelaksanaan pembelajaran dengan pendekatan manajemen beginning of effective teaching

Pelaksanaan pembelajaran mata
kuliah Konsep Dasar Pendidikan
Kewarganegaraan dengan penerapan
manajemen beginning of effective teaching
dilaksanakan dalam 3 pertemuan $(2 \times 100$
menit) di rombel 6 dengan jumlah peserta
40 orang. Pertimbangan pemilihan rombel 6
karena rombel ini yang memiliki
kemampuan sedang cenderung rendah
(rata-rata nilai awal kurang dari 60) dan
berdistribusi normal.

Tabel 1. Output Hasil Analisis Deskriptif Dengan SPSS 16.0 Data Awal Rombel 6

\begin{tabular}{|l|l|l|l|l|l|}
\hline & N & Minimum & Maximum & Mean & $\begin{array}{l}\text { Std. } \\
\text { Deviation }\end{array}$ \\
\hline Data & 40 & 20.00 & 80.00 & 44.1250 & 14.09162 \\
Awal & 40 & & & & \\
Valid N \\
(listwise)
\end{tabular}

Diperoleh mean (rata-rata) data awal pada rombel 6 adalah 44,125. Untuk uji normalitas data awal digunakan uji Kolmogorov-Smirnov

Table 2. Output Hasil Uji Normalitas Dengan SPSS 16.0 Data Awal Rombel 6

\begin{tabular}{|l|l|l|l|l|l|l|}
\hline & \multicolumn{3}{|l|}{$\begin{array}{l}\text { Kolmogorov- } \\
\text { Smirnov }\end{array}$} & \multicolumn{3}{l|}{ Shapiro-Wilk } \\
\cline { 2 - 7 } & Statistic & Df & Sig. & Statistic & df & Sig. \\
\hline VAR00001 & -165 & 40 & .008 & .956 & 40 & .126 \\
\hline
\end{tabular}

Dari output diperoleh taraf signifikan $0.008=8 \%$ lebih dari $5 \%$ maka disimpulkan data berdistribusi normal.

Kegiatan perkuliahan diawali dengan

a) Opening (pembuka)

Proses opening sangat penting dilakukan untuk dapat menarik perhatian peserta didik sehingga mereka akan mau mengikuti proses belajar mengajar yang akan dilakukan. Dalam proses ini dapat dilakukan dengan teknik SSD (Showing Something Different) yaitu dengan menampilkan sesuatu yang berbeda.

b) Ice breaking (menumbuhkan semangat)

Dalam proses ini dilakukan dengan memberikan preview dan review, yaitumemberikan penjelasan kepada peserta didik terkait materi pelajaran yang sudah diajarkan dan memberikan umpan balik melalui kegiatan pre test untuk meninjau seberapa jauh peserta didik memahami materi pelajaran.

c) Presentation (mengajarkan materi pelajaran)

Dalam proses ini adalah mengajar materi sesuai dengan standar 
kompetensi yang telah ditentukan. Mengajar dengan cara singkat dan sederhana namun mudah dipahami

d) Exercises and correction (latihan dan koreksi)

Proses ini dilakukan dengan meminta peserta didik membuat kelompok belajar di dalam kelas, kemudian memberi latihan terkait materi yang baru diajarkan. Setiap peserta didik dalam kelompok harus aktif memecahkan masalah

e) Students talk time (waktu berbicara peserta didik)

Proses ini dilakukan dengan cara memperhatikan peserta didik yang sedang melakukan latihan (Tanya jawab dan menjelaskan) dalam kelompok belajar, namun tidak melakukan koreksi atas kesalahan-kesalahan mereka.

f) Explanation conclusions and closing (kesimpulan penjelasan dan penutupan)

Dalam proses ini dilakukan dengan memberi penjelasan kesimpulan yang lebih memahamkan peserta didik terkait materi yang diajarkan dan melakukan kegiatan postest.

Selama kegiatan pembelajaran dilakukan pengamatan terhadap jalannya pembelajaran dengan pendekatan penerapan manajemen beginning of effective teaching. Pengamatan dilakukan oleh anggota penelitisebanyak dua orang, satu orang mengamati pelaksanaan pembelajaran dengan pendekatan penerapan manajemen beginning of effective teaching dan yang lain mengamati kualitas pembelajaran.

\section{Pemahaman mahasiswa sebelum dan} sesudah pembelajaran dengan Pendekatan Manajemen Beginning of Effective Teaching

Data kuantitatif yang dianalisis adalah tingkat pemahaman kontekstual mahasiswa. Tahap yang harus dilaksanakan untuk menganalisis data adalah: a) Menguji normalitas data

Uji normalitas dilakukan pada hasil pre test dan hasil post test berikut hasil uji normalitas dengan menggunakan software SPSS 16.00.

Tabel 3. Output Hasil Uji Normalitas dengan SPSS 16.0 Data Pre test

\begin{tabular}{|l|l|l|l|l|l|l|}
\hline \multicolumn{1}{|c|}{} & \multicolumn{2}{|l|}{$\begin{array}{l}\text { Kolmogorov- } \\
\text { Smirnov }\end{array}$} & \multicolumn{3}{l|}{ Shapiro-Wilk } \\
\cline { 2 - 6 } & $\begin{array}{l}\text { Statisti } \\
\text { c }\end{array}$ & $\begin{array}{l}\text { D } \\
\text { f }\end{array}$ & Sig. & $\begin{array}{l}\text { Statisti } \\
\text { c }\end{array}$ & df & Sig. \\
\hline VAR0000 & .126 & 4 & .10 & .966 & 4 & $\begin{array}{l}.27 \\
1\end{array}$ \\
\hline
\end{tabular}

Dari tabel diperoleh signifikan untuk test Kolmogorov Smirnov 0,108 $=10,8 \%$ nilainya lebih dari $5 \%$ sehingga dikatakan data hasil pretest berdistribusi normal.

Tabel 4. Output Hasil Uji Normalitas dengan SPSS 16.0 Data Post test

\begin{tabular}{|l|l|l|l|l|l|l|}
\hline \multirow{2}{*}{} & \multicolumn{2}{|l|}{$\begin{array}{l}\text { Kolmogorov- } \\
\text { Smirnov }\end{array}$} & \multicolumn{3}{l|}{ Shapiro-Wilk } \\
\cline { 2 - 6 } & $\begin{array}{l}\text { Statisti } \\
\mathrm{c}\end{array}$ & $\begin{array}{l}\mathrm{D} \\
\mathrm{f}\end{array}$ & Sig. & $\begin{array}{l}\text { Statisti } \\
\mathrm{c}\end{array}$ & $\mathrm{df}$ & Sig. \\
\hline VAR0000 & .117 & $\begin{array}{l}4 \\
0\end{array}$ & .18 & .935 & $\begin{array}{l}4 \\
0\end{array}$ & $\begin{array}{l}.02 \\
4\end{array}$ \\
\hline
\end{tabular}

Dari tabel diperoleh nilai signifikan test Kolmogorov Smirnov adalah $0.181=18,1 \%$, nilai ini melebihi 5\% sehingga data hasil post test berdistribusi normal.

4. Uji peningkatan tingkat pemahaman konseptual mahasiswa sesudah penerapan Pendekatan Manajemen Beginning Of Effective Teaching

Uji beda ini menggunakan software SPSS 16.00, dengan paired samples correlations. Hipotesis yang diajukan adalah :

Ho = rata-rata hasil pre test dan posttest sama

$\mathrm{H} 1$ = rata-rata hasil pre test dan post test berbeda.

Tabel 5. Output Hasil Uji Beda Data Pre test Dan Post test dengan SPSS 16.00

\begin{tabular}{|c|c|c|c|c|c|c|c|c|}
\hline & \multicolumn{5}{|c|}{ Paired Differences } & \multirow[t]{3}{*}{$\mathrm{T}$} & \multirow[t]{3}{*}{$\mathrm{df}$} & \multirow[t]{3}{*}{ Sig. (2-tailed) } \\
\hline & \multirow[t]{2}{*}{ Mean } & \multirow[t]{2}{*}{$\begin{array}{l}\text { Std. } \\
\text { Deviation }\end{array}$} & \multirow{2}{*}{$\begin{array}{l}\text { Std. } \\
\text { Error } \\
\text { Mean }\end{array}$} & \multicolumn{2}{|c|}{$\begin{array}{l}\text { 95\% Confidence Interval } \\
\text { of The difference }\end{array}$} & & & \\
\hline & & & & Lower & Upper & & & \\
\hline $\begin{array}{l}\text { Pair 1 Pretest- } \\
\text { Postes }\end{array}$ & $-3.97500 \mathrm{E} 1$ & 18.22052 & 2.88092 & -45.57720 & -33.92280 & -13.798 & 39 & \\
\hline
\end{tabular}

Nilai t dihitung sebesr -13,793 dengan sig 0.000. Karena Sig. kurang dari 5\% maka dapat disimpulkan bahwa Ho ditolak, dan
H1 diterima. Artinya ada perbedaan ratarata hasil pretest dan rata-rata hasil posttest. Dengan demikian dapat dikatakan bahwa ada peningkatan pemahaman mahasiswa 
sebelum pembelajaran dengan Pendekatan Manajemen Beginning Of Effective Teaching dan sesudah menggunakan Pendekatan Manajemen Beginning of Effective Teaching

\section{SIMPULAN}

Berdasarkan hasil penelitian maka dapat disimpulkan bahwa penerapan pendekatan Manajemen Beginning Of Effective Teaching dalam pembelajaran Pendidikan Kewarganegaraan di PGSD UNNES dapat meningkatkan pemahaman bagi mahasiswa PGSD UNNES. Peningkatan pemahaman ditunjukkan dengan peningkatan hasil belajar dari prê test (sebelum pembelajaran dengan menggunakan pendekatan Manajemen Beginning Of Effective Teaching ) mencapai rata-rata 35,0 menjadi hasil belajar dari post test (sesudah pembelajaran dengan menggunakan Manajemen Beginning Of Effective Teaching ) mencapai rata-rata 74,6.

\section{DAFTAR PUSTAKA}

Afifi, John. 2014. Inovasi-Inovasi Kreatif Manajemen Kelas dan Pengajaran Efektif. Yogyakarta: Diva Press.

Daryanto. 2010. Media Pembelajaran Peranannya Sangat Penting dalam Mencapai Tujuan Pembelajaran. Yogyakarta: Gava Media.

Depdiknas. 2004. Peningkatan Kualitas Pembelajaran. Jakarta: Direktorat Jenderal Pendidikan Tinggi Departemen Pendidikan Nasional.
Hamalik, Oemar. 2001.Proses Belajar Mengajar.Jakarta: PT Bumi Aksara.

Majid, Abdul. 2013. Strategi pembelajaran. Bandung: Rosda Karya.

Sumantri, Mulyani dan Johar Permana. 2001. Strategi Belajar Mengajar. Bandung: CV. Maulana.

Sugiyono. 2015. "Metode Penelitian Pendidikan Pendekatan Kuantitatif,Kualitatif, dan $R \& D$ '. Bandung : Alfabeta

Suprijono, Agus. 2009. Cooperative Learning Teori dan Aplikasi Paikem. Yogyakarta: Pustaka Pelajar.

Ruminiati. 2007. Pengembangan Pendidikan Kewarganegaraan SD. Jakarta: Direktorat Jenderal Pendidikan Tinggi Departemen Pendidikan Nasional.

Rahardja, Ps. Widi. 2002. Sekitar Strategi Belajar Mengajar dan Keterampilan Mengajar. Salatiga: Fakultas Keguruan dan Ilmu Pendidikan Universitas Kristen Satya Wacana.

Wahab, Azis. 2007. Pendidikan Pancasila dan Kewarganegaraan. Jakarta. Universitas Terbuka

Winarno. 2013. Pembelajaran Pendidikan Kewarganegaraan. Jakarta: Bumi Aksara 